$\rho_{B}=$ apparent density of powder
$\phi \quad=$ volume fraction of larger particles $\left[\mathrm{g} \cdot \mathrm{cm}^{-3}\right] \quad$ Literature cited

$[-]$
1) Yamashiro, M. and H. Kuno: Kagaku Kogaku Ronbunshu, 14, 46 (1988)

\title{
Effect of Efflux Tube Size on Gravity Flow of Powders from a Hopper
}

\section{Mitsuo Yamashiro}

Dept. of Industrial and Systems Eng. Ashikaga Inst. of Tech., Ashikaga 326

\section{Hiroshi Kuno}

Dept. of Applied Chemistry, Keio Univ., Yokohama 223

Key Words : Hopper, Powder, Gravity Flow, Efflux Tube, Efflux Rate

Additional experiments on gravity flow of powders from a hopper were carried out by varying the diameter of the efflux tube, $\boldsymbol{D}$, to reconfirm the following semi - theoretical equation :

$$
\boldsymbol{W}=\boldsymbol{C} \rho_{B}^{1 / 2}\left(\boldsymbol{P}_{2}-\boldsymbol{P}_{1}\right)^{1 / 2}\left(\boldsymbol{D}-\boldsymbol{k} \boldsymbol{d}^{1 / 2}\right)^{2}
$$

where $\boldsymbol{W}$ is the efflux rate of powder; $\rho_{B}$ the apparent density of the powder in the hopper ; $\boldsymbol{P}_{2}$ and $\boldsymbol{P}_{1}$ the pressure above and below the orifice; $\boldsymbol{d}$ the particle diameter ; and $\boldsymbol{C}$ and $\boldsymbol{k}$ are constants.

\section{凍結乾燥における凍結粒子の濡れ壁塔を用いた連続製造法 ${ }^{\dagger}$ \\ 横田俊幸・大戸行雄 \\ 山形大学工学部 化学工学科 $^{\dagger \dagger}$}

凍結乾燥法による金属酸化物の微粉体の製造は，活性 の高い粉体が得られることから、ファインセラミックス 用の原料粉体の製造法として大いに注目を浴びている. この方法は，1968年 Schnettler ら ${ }^{5)}$ によって提案されて いらい, 多くの研究がなされその有用性が示されている ${ }^{1,2,3)}$ が，いまだ工業的規模での応用はなされず，実験室 的利用にとどまっている，その理由として，プロセスの 連続化が難しい, 装置が高価である，また乾燥過程に時 間がかかる，などが挙げられている。

本報告では, 凍結乾燥プロセスの中の凍結操作を取り

† 1988年 9 月28日受理; 化学工学協会第20回秋季大会（姫路, 1987年10月）にて 部発表

计 $\mathbf{9} 992$ 米沢市城南 4-3-16
上げ，微小液滴の凍結を効率的に行い，工業的規模での 利用も可能な新しい凍結粒子製造装置を開発したので報 告する.

てれまでの凍結粒子の製造法は, Schnettler らが提案 した方法と基本的には変わらず, 凍結バス中に液柱ある いは液滴を噴霧し，乙れを凍らすむのである。乙の方法 の問題点として，回分方式であるため処理量に制限があ る, 原料溶液の注入量が増えると凍結バスの温度が変化 する, 注入した液滴同士の衝突, 合一や凍結粒子の凝集 が起きることがある，凍結粒子の捕集に手間がかかる， などがある，連続式の凍結粒子製造法としはSauer ら ${ }^{4)}$ が提案した方法がある。乙れは, 低温窒素ガスにて冷や した有機化合物の冷媒の中に, 原料の金属塩水溶液を泠 


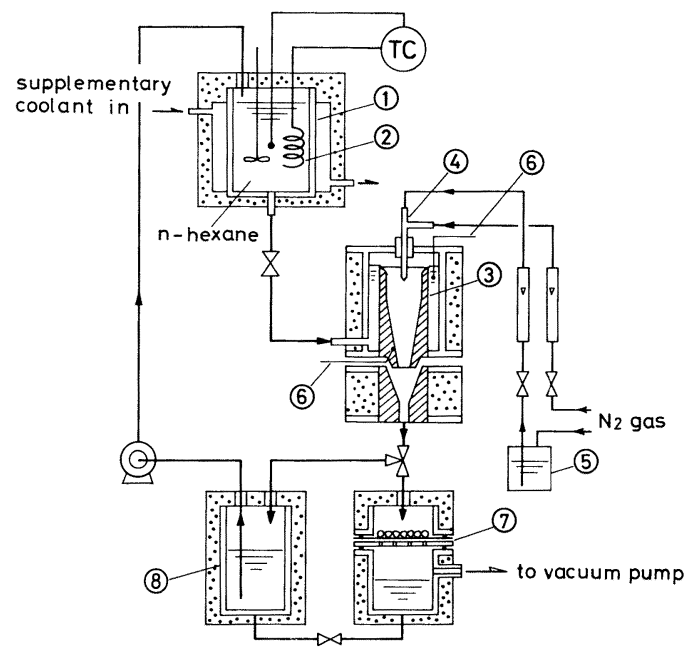

Fig. 1 Wetted-wall column type freezing apparatus

(1) Head tank of refrigerant

(2) Dipped cooler

(3) Wetted-wall column

(4) Pneumatic spray nozzle

(5) Feed solution tank

(6) C-C thermocouple

(7) Filtration apparatus

(8) Storage tank of refrigerant

媒下部のノズルから注入して急冷し，上部に浮き上がっ た凍結粒子をかきだす方法である。乙の装置で，ノズル 径や，水溶液の注入圧力を変えるととにより，平均粒径 が $0.4 \mathrm{~mm}$ から $2.0 \mathrm{~mm}$ の硫酸アルミニウムの凍結粒子を 得たと報告している。

\section{凍結粒子製造装置}

本装置は，冷媒を濡れ壁塔形式で流下させ，そこに原 料水溶液を噴霧して液滴を涷結させる方式のものである. 凍結装置全体の概略図を Fig. 1 亿, 濡机壁式凍結部の詳 細をFig. 2 に示す.

凍結乾燥のための凍結装置として必要な条件をあげる 之，1) 組成の偏析を抑えるために凍結速度が十分速いて と，2）液滴同士の合一や涷結粒子の凝集が無いとと，3) 凍結粒子の粒径が小さいとと，4) 凍結粒子の捕集が容易 なとと、などがある。凍結粒子の粒径が小さいと，次の 乾燥操作の時間を短縮でき，また，仮焼操作においてす ガスの放出が容易となり，必要以上の熱を与えることが 少なくなるため，結晶子の小さな酸化物粒子が得られる。

本装置では。二流体ノズルを用いて微小液滴を作るた め。液滴径は小さく凍結速度も十分速い，本装置に用い たノズルは，液側ノズル内径 $0.3 \mathrm{~mm}$ ，ガス側ノズルの内 側外径 $1.0 \mathrm{~mm}$ ，外側内径 $1.6 \mathrm{~mm}$ のガラス製のものであ る. 通常, 回分式の凍結バスへ二流体ノズルにて液滴を噴 霧すると，バスに捕集できない液滴が回りに飛び散って,

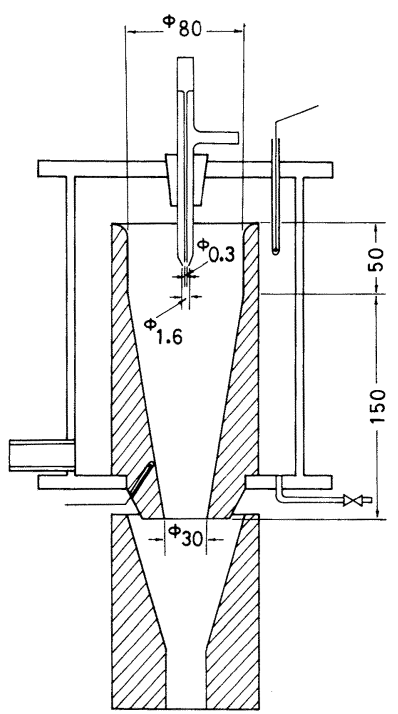

Fig. 2 Detail of wetted-wall column type freezer

捕集効率は非常に悪い。本装置では，濡れ壁塔の下部を 絞り込み (勾配 80.5 度のテーパー管とした)，乙の中で 液滴を噴霧するためその捕集はほぼ完全であった。二流 体ノズルの噴霧用同伴ガスには窒素ガスを用いた。 この ガスは濡机壁塔とその下部に設けた冷媒捕集用の漏斗の すきまから，系外へ抜け出た。冷媒の温度は，流下する 液膜に液滴を吹き付けるためほとんど変化せず，そのた め涷結速度屯常に一定亡なった。液滴同士の合一や，凍 結粒子の凝集も非常に小さく抑えることができた。

本装置の操作上の問題点は, 噴霧液量および同伴ガス の量が多すぎると, 冷媒の液膜を吹き切ってしまうこと である，液膜を吹き切ると，壁面で液滴の凍結が起こり 凍結粒子が付着し，正常な操作ができなくなる，そのた め, 原料の噴霧条件を適切侸設し, 冷媒流量を加減す るととにより適当な厚さの液膜を確保するととが大切で ある。

凍結粒子の捕集は，滤過装置によって行った，凍結粒 子を濾紙上に（直径 $14 \mathrm{~cm}$ ) 捕集し, 乙れを濾紙ごと乾燥 装置に移し減圧乾燥した。原料の噴霧を間欠的に行い, そのつど下方の三方コックを切り替えて凍結粒子を捕集 する半連続操作によって凍結粒子を得た，冷媒の量を十 分確保できれば，かなり大量の原料溶液を処理するてと ができ，工業規模での利用も可能と考えている.

\section{実験および結果}

原料として，硫酸マグネシウム水溶液（金属イオンモ ル濃度 $\left.1 \times 10^{3} \mathrm{~mol} / \mathrm{m}^{3}\right)$ 抢よび硫酸了ルミ二ウムと硫酸 マ.グネシウムのスピネル比混合水溶液 $\left(\mathrm{MgAl}_{2}\left(\mathrm{SO}_{4}\right)_{4}\right.$ と してのモル濃度 $\left.0.5 \times 10^{3} \mathrm{~mol} / \mathrm{m}^{3}\right)$ の種類を用いて実験 


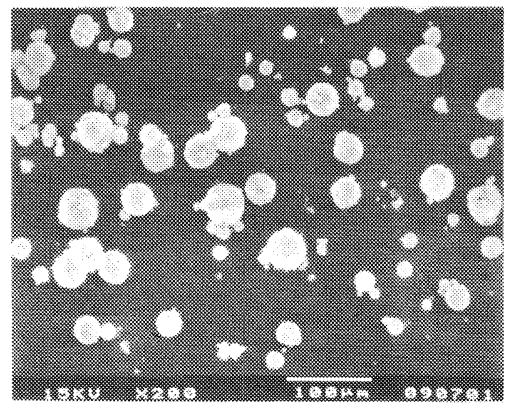

(a)

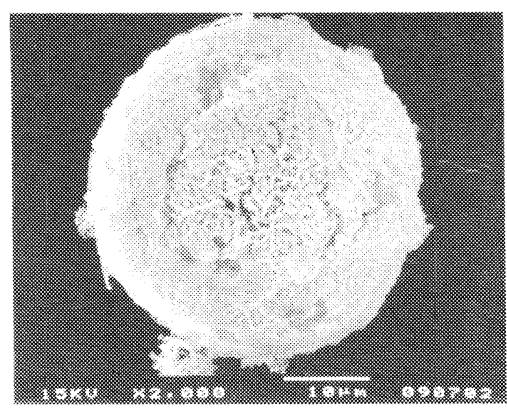

(b)

Fig. 3 Scanning electron micrographs of freeze dried particles

(a) Appearance of magnesium sulfate particles

(b) Surface of a freeze dried particle

した。溶液の噴霧条件は次のように定めた。液供給流量 $0.167 \mathrm{~cm}^{3} / \mathrm{s}$ (ノズル断面積基準の液流速 $2.36 \mathrm{~m} / \mathrm{s}$ ), ガス 供給量 $167 \mathrm{~cm}^{3} / \mathrm{s}$ (ノズル断面基準のガス流速 $136 \mathrm{~m} / \mathrm{s}$ ). その結果，噴霧角 (ノズル真下の紡錘形噴霧部の頂角) は60度となり, 液滴径分布は以下に述べる凍結乾燥粒子 の粒径分布にほぼ等しい分布となった。

冷媒には $\mathrm{n}$ ーヘキサンを用い，冷媒温度を $-70 \pm 1^{\circ} \mathrm{C}$ に 制御した。冷媒の冷却には投げ込みクーラーを用い, 補 助冷却媒体として液体窒素を用いた。. 冷媒流量は, $83 \mathrm{~cm}^{3}$ / $\mathrm{s}$ とし, 濡れ壁上部での液膜厚さは約 $0.4 \mathrm{~mm}$ となった。 液滴噴霧中の冷媒の温度変化を測定した結果, $1^{\circ} \mathrm{C}$ 以下 となった。

凍結乾燥粒子の外観 SEM 像捛よび表面の拡大図を Fig. 3 亿示す. 凍結乾燥粒子にはダンベル状の粒子や凝 集状態の粒子はほとんど見られず，液滴同士の合一や凍 結中の粒子の凝集はほとんど無いととがわかった。また 表面の拡大写真加 , 乾燥粒子は皮の昇華した跡が粒子 全体に広がっている多孔質の粒子であるてとがわかった。 凍結乾燥粒子の粒度分布の測定結果を Fig. 4 亿示す. 平 均粒径は $42.5 \mu \mathrm{m}$ となった。一般に, 噴霧液滴径と乾燥

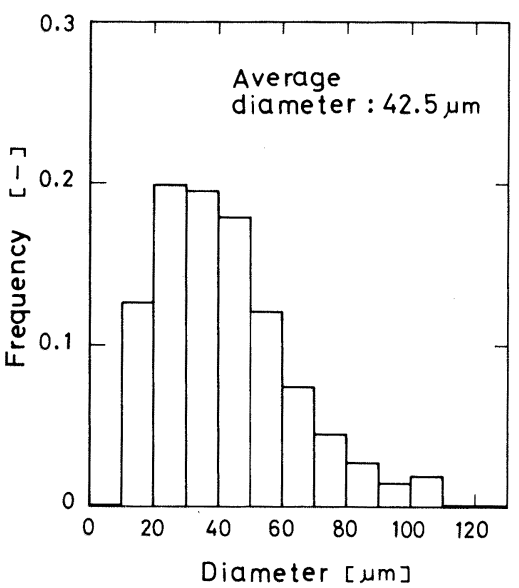

Fig. 4 Size frequency distribution of freeze dried particles

粒子径とはほぼ等しくなると言わ机ているが゙) 本実験 においてもこのことは確認できた。

次に，凍結時の組成の偏析について調べた結果を述べ る. $\mathrm{Al}-\mathrm{Mg}$ スピネル量論比の硫酸塩水溶液を凍結乾燥 し，乙机を熱分解してスピネル化反応を行い $\mathrm{Mg} \mathrm{Al}_{2} \mathrm{O}_{4}$ を得た。乙のときスピネル以外に $\mathrm{MgO}$ 拉よび $\mathrm{Al}_{2} \mathrm{O}_{3}$ が 生成したか否かをX線分析にて测定するてとによって偏 析の有無を調べた ${ }^{6)}$. その結果, 冷媒温度が $-70^{\circ} \mathrm{C} の$ 時 には偏析は見られなかった。しかし冷媒温度が $-50^{\circ} \mathrm{C}$ 以 上ではわずかではあるが偏析が認められた。これは，液 滴とへキサンとの接触時間が短いため（最大で約 0.5 秒） 冷媒温度が高い場合には，一部の液滴が完全に凍結する 前にへキサンから分離され, その後濾過装置上で涷結し たためと思わ机る。乙のととから，冷媒の温度を十分低 くし，冷媒との接触時間屯適当に取り，また液滴の大き さむ制御することにより，凍結速度を大きくして組成の 偏析を防ぐことが大切である。

以上の実験結果から，本報告にて述べた凍結装置は， 微小液滴を効率よく捕集して涷結し，凝集の少ない組成 偏析の無い凍結粒子を得るととができた。また，乙の装 置之濾過装置を組み合わせ，半連続操作によって多量の 原料溶液を処理することができた。

\section{Literature cited}

1) Mihara, T.: Ceramics Japan, 16, 848 (1981)

2) Ozaki, Y.: Kagaku Kogaku, 46, 535 (1982)

3) Sasamoto, T. and N. Torikai: Hyomen (Surface), 22, 708 (1984)

4) Sauer, H.A. and J.A.Lew is: AIChE J., 18, 435 (1972)

5) Schnettler, F.J., F.R. Monforte and W.W. Rhodes: Science of Ceramics, 4, 79 (1968)

6) Yokota, T., Y.Abe and H.Koseki: Kagaku Kogaku Ronbunshu, 13, 542 (1987) 


\title{
A Continuous Method for Freezing Droplets by a Wetted-Wall Column in Freeze Drying
}

\author{
Toshiyuki Yokota and Yukio Ohto
}

\begin{abstract}
Dept. of Chem. Eng., Yamagata Univ., Yonezawa 992
Key Words : Freeze Drying, Wetted-Wall Column, Frozen Droplets, Segregation, Pneumatic Spray Nozzle

A new continuous method for freezing droplets has been developed in freeze drying. A wetted-wall column with a conical tail was used, with a flow of cooled n-hexane as refrigerant. In the column a feed solution was sprayed through a pneumatic spray nozzle. Sprayed fine droplets were caught in the falling refrigerant. Frozen particles were screened by filtration. Advantages of the method are that i) almost all fine droplets can be caught, ii) rapid cooling is accomplished, thus preventing component segregation, and iii) very fine frozen particles with little agglomeration are produced.
\end{abstract}

\section{符号付有向グラフを用いた化学プロセスの異常診断法 \\ 一 異常発現時刻の概念の拡張 $-^{\dagger}$ \\ 具嶋文彦・柴田望洋・潮崎淳一 * \\ 松山久義・大島榮次** \\ 九州大学工学部 化学機械工学科 ${ }^{\dagger \dagger}$}

前報 ${ }^{1)}$ 亿扔いて診断対象システムの状態変数の経時変 化 (動的症状) の特徴を, 状態变数が異常を示す時刻 (異 常発現時刻）によって表現して符号付有向グラフによる 診断法の精度を向上させる方法を提案し, 槽・配管系に 扣いてその効果を確かめたが, この方法は，全ての測定 変数が同一のサンプリング周期で同時刻に測定されてい ることを前提としていた.

しかし，既存の計装システムに異常診断システムを付 加する場合には, 変数の測定時刻がまちまちであること が多く，前報で示した異常発現時刻を利用した診断法を そのまま適用することはできない。

ここでは, 測定時刻が変数によって異なる場合に, 異 常発現時刻の概念を拡張する方法について報告する.

† 1988年 9 月22日受理

†† 812 福岡市東区箱崎 6-10-1

* 山武八ネウェル(株)

*** 東京工業大学 資源化学研究所

\section{異常発現時刻の概念の拡張}

診断対象システムの測定変数の值 $\mathrm{x}$ が正常か異常かを, 5 段階パターン ${ }^{2)}$ にり表現する。５段階パターンにお いては，第 1 種のしきい值 $\mathrm{a}^{-}, \mathrm{a}^{+}$と第 2 種しきい值 $\mathrm{b}^{-}$, $\mathrm{b}^{+}$を用いる。第 1 種のしきい值は， $\mathrm{a}^{-} \leqq \mathrm{x} \leqq \mathrm{a}^{+}$のとき自 信を持って正常と判定できるしきい值であり，乙のとき， $\mathrm{x}$ に対応する符号付有向グラフ上の点に符号「0」を与え る.第 2 種のしきい值は, $\mathrm{x}<\mathrm{b}^{-}\left(\right.$または $\mathrm{x}>\mathrm{b}^{+}$)である とき自信を持って異常であると判定できるしきい值であ り，乙のときxに対応する点に符号「一」(または「十」) を与える. $\mathrm{b}^{-} \leqq \mathrm{x}<\mathrm{a}^{-}$のとき符号を「-?」, $\mathrm{a}^{+}<\mathrm{x} \leqq \mathrm{b}^{+}$ のとき符号を「+?」として，乙れらの符号を持つ測定点 をあいまい測定点と呼び，「十」，「-」を「+?」，「-?」 に対応する有効な符号と呼ぶ。 また，「0」，「十」,「一」 を持つ測定点を確定測定点と呼ぶ.

前報では, 第 1 種のしきい值を初めて越える時刻を第 1 種の異常発現時刻, 第 2 種のしきい值を初めて越える 